\title{
Бухурова М.М. \\ Фольклорные истоки образа богатыря в адыгских литературных сказках
}

Институт гуманитарных исследований - филиал ФГБНУ «Федеральный научный иентр «Кабардино-Балкарский научный центр Российской академии наук»

doi: 10.18411/trnio-09-2021-88

(Россия, Нальчик)

\section{Аннотация}

Литературная сказка является одной из самых популярных и художественно совершенных жанровых разновидностей адыгской литературы. Однако, несмотря на это, она до сих пор остается малоизученной. Этим обстоятельством обусловлены актуальность обозначенной темы и научная новизна настоящего исследования. Цель работы - определение роли фольклорных элементов в создании образов персонажей литературной сказки адыгов. В качестве объекта исследования рассматриваются произведения кабардинских писателей Алима Кешокова и Нури Шогенцукова. Для сравнения привлекаются также народные сказки - волшебные, богатырские и др.

Ключевые слова: адыгская литературная сказка, богатырская сказка, фольклор, богатырь, мотив, образ.

\section{Abstract}

The literary tale is one of the most popular and artistically perfect genre varieties of the Adyg literature. However, despite this, it still remains poorly studied. This circumstance determines the relevance of the indicated topic and the scientific novelty of this study. The purpose of the work is to determine the role of folklore elements in the creation of images of the characters of the literary tale of the Circassians. The object of research is the works of Kabardian writers Alim Keshokov and Nuri Shogentsukov. For comparison, folk tales are also involved - magic, heroic, etc.

Keywords: Adyg literary tale, heroic tale, folklore, hero, motive, image.

В филологической науке существует ряд определений термина «литературная сказка». По мнению известного филолога И.З. Сурат, это - «жанр, соединяющий в себе черты индивидуального авторского творчества с использованием в большей или меньшей степени некоторых фольклорных канонов - образных, сюжетно-композиционных, стилистических» [8, с. 263]. Ю.Ф. Ярмыш определяет литературную сказку как «жанр литературного произведения, в котором в волшебно-фантастическом или аллегорическом развитии событий, и, как правило, в оригинальных сюжетах и образах в прозе, стихах или драматургии решаются морально-этические и эстетические проблемы» [10, с. 179]. По справедливому замечанию Л.Ю. Брауде, «литературная сказка - авторское художественное прозаическое или поэтическое произведение, основанное либо на фольклорных источниках, либо придуманное самим писателем, но в любом случае подчиненное его воле; произведение, преимущественно фантастическое, рисующее чудесные приключения вымышленных или традиционных сказочных героев и в некоторых случаях ориентированное на детей; произведение, в котором волшебство, чудо играет роль сюжетообразующего фактора, помогает охарактеризовать персонажей» [4, с. 7]. Как видно, ученые описывают одно и то же литературное явление, но разными словами, а их суждения во многом дополняют друг друга, и как можно заметить, все они обращают внимание на то, что основными истоками литературной сказки являются фольклорные мотивы. Другими словами, она берет свое начало в фольклоре, и в них преобладают элементы этого вида словесного искусства.

Прежде чем охарактеризовать эти элементы, хотелось бы отметить общие черты и отличия литературной и народной сказок. Одно из главных отличий - это наличие автора у литературной сказки, в то время как создателем сказки фольклорной является народ. 
Авторская сказка может быть как в прозе, так и в стихах, а народная - только в прозаической форме. Темой народной сказки чаще всего выступает противостояние добра и зла, а в авторской сказке мораль и поучение могут быть на любую тему. В литературной сказке язык повествования - любой, в народной - сказочный язык, с характерными выражениями и оборотами. Еще одним важным отличием является то, что авторские сказки сочиняются и одновременно фиксируются на бумаге, а народные чаще всего передаются из уст в уста. Можно также выделить сходства. И в тех и в других случаях добро побеждает зло. По жанровым признакам и литературные, и фольклорные сказки чаще всего делятся на три вида: волшебные, сказки о животных и бытовые. Существуют и такие виды сказок как кумулятивные, докучные и небылицы. В них часто присутствуют волшебные предметы, магия, превращения и т.д. Как правило, есть центральный герой, вокруг которого группируются другие (второстепенные) персонажи - помощники, противники, чудесные предметы и пр.

При сравнении этих двух разновидностей сказок обнаруживаются и другие сходные моменты, каковыми являются «отдельные средства поэтического языка, архаические мотивы и даже целые сюжеты, как, например, рождение или происхождение героя, богатырское детство, чудесные свойства оружия и коня и т.д.» [6, с. 204].

Конечно же, в небольшой статье невозможно охватить все произведения данного жанра. Поэтому для рассмотрения были выбраны такие сказки как «Бранду» [9] Нури Шогенцукова и «Эльбездуко» [7] Алима Кешокова, в которых обнаруживается наибольшее сходство с фольклорной сказкой, а именно - с так называемой богатырской сказкой.

Главный герой сказки Н. Шогенцукова «Бранду» - самый младший из трех братьев. При чтении этого произведения сразу же бросается в глаза то, что автор наделил этого персонажа чертами «низкого» героя, который характерен для многих фольклорных сказок. Как правило, подобный герой адыгской сказки третий или самый младший из нескольких сыновей бедного старика (в вариантах - вдовы). Старшие братья относятся к нему как к неполноценному человеку, недолюбливают его, морят голодом. Под разными предлогами они уклоняются от выполнения своих обязанностей, перекладывая это на плечи младшего брата. Несмотря на это, «не подающий надежд» оказывается героем: он скрывает свои подлинные достоинства, между тем, именно он совершает подвиг» [5, с. 65].

Так, например, в богатырской сказке «Зы къуажэ гуэрым зы лІыфІ гуэр дэст» («В одном селе жил добрый муж») [2] таким героем является Кьуиижь цІыкІу (Маленький плешивец). Его занятие - пасти коз, и это позволяет отнести его к типу «низкого» героя, однако только он, благодаря своей храбрости и физической силе, одолевает антагонистов. Сюжет сказки можно отнести к общефольклорным. В международном указателе сказочных сюжетов Аарне-Томпсона [11] он встречается под номером АТ 530 «Волшебный конь»: «Перед смертью отец завещает сыновьям три ночи караулить его могилу. Завещание отца выполняет только младший из братьев. На могиле отца он получает чудесных коней, с помощью которых женится на дочери князя-пши» [1, с. 28].

Как повествуется в литературной сказке Нури Шогенцукова, у одного бывалого охотника рождаются трое сыновей: Чигаду, Дамаду, Бранду. Старшие (Чигаду и Дамаду) считают младшего (Бранду) «никчемным», но он единственный, кто выполняет завещание отца, что характерно для данного типа героя: Бранду охраняет его могилу. Три ночи подряд он одолевает иныжей (великанов), которые приезжают на волшебных конях, чтобы осквернить могилу, после чего Бранду получает этих коней, и при помощи их достигает сказочной цели. Он женится на дочери князя.

В отличие от Нури Шогенцукова, Алим Кешоков в своей литературной сказке «Эльбездуко» использовал сказочный сюжет АТ 3І3Н* под названием «Бегство от ведьмы». Очень часто в народных сказках на этот сюжет вместо ведьмы фигурирует иныж, однако и в 
том, и в другом случае персонажи и волшебные предметы выполняют одну и ту же функцию: главный герой спасается от преследования иныжа (ведьмы, железного волка и т.п.) с помощью бросания чудесных предметов. Чаще всего это расческа, зеркало, ножницы, которые превращаются в преграды на пути антагониста.

В архивном фонде ИГИ КБНЦ РАН хранится одноименная сказка «Эльбездуко» [3]. На наш взгляд, именно она стала основой рассматриваемой литературной сказки. Как и Бранду, Эльбездуко - самый младший из трех братьев, и старшие издеваются над ним. У них есть одна кобылица, которая жеребится каждый год. Но иныж крадет его у братьев, и они решают охранять его. Однако это удается только младшему - Эльбездуко. Здесь мы видим один из распространенных в мировом фольклоре и литературе художественных приемов идеализации центрального персонажа. В начале произведения герой выглядит слишком юным, он все время проводит у очага. А старшие - известные наездники, дразнят его, не доверяют. Однако, неожиданно для всех, самый младший совершает подвиг и одолевает многоголового иныжа.

Подобное сочетание черт является способом привлечения внимания слушателя. Другими словами, центральный герой должен отличаться от других своим происхождением, чудесным рождением, быстрым ростом и т.п. В данном случае он - «не подающий надежд». Но только он может достигнуть сказочной цели. И, как видно, Алим Кешоков с большим мастерством использовал этот прием. Только Эльбездуко удается обнаружить вора. Им оказался, как уже было сказано, семиглавый иныж. Эльбездуко ранит его, но он убегает. Богатырь отправляется на его поиски, и в пути встречает одинокую старушку. Как и в народных сказках, после совершения ритуала усыновления, старушка оказывает ему всевозможную помощь: дарит ему чудесные предметы (расческу, зеркало, ножницы). Далее сюжет развивается по схеме АТ 3І3H*: Эльбездуко отправляется к иныжу, освобождает плененную им девушку, и вместе они пускаются в обратный путь. Иныж, с намерением догнать их, бежит за ними. Но, как это принято в сказках с данным сюжетом, с помощью бросания чудесных предметов Эльбездуко и девушка спасаются от преследования иныжа. В финале произведения он убивает великана.

Как видно, Алим Кешоков и Нури Шогенцуков в своих сочинениях, пользуясь фольклорными традициями, воссоздали литературный образ богатыря. В литературных сказках названых писателей доминирующее положение занимают не только отдельные характеристики сказочных персонажей, но и мотивы, и даже целые сюжетные ходы, сформировавшиеся в народных сказках адыгов, и все это в совокупности определяют оригинальность созданных ими произведений вообще и каждого образа в частности.

$$
* * *
$$

1. Алиева А.И. Поэтика и стиль волшебных сказок адыгских народов. М.: «Наука», 1986. 280 с.

2. Архив ИГИ КБНЦ РАН. Ф. 12. Оп. 1. Папка № 6-г. Паспорт № 9.

3. Архив ИГИ КБНЦ РАН. Ф. 12. Оп. 1. Папка № 7-в. Паспорт № 11.

4. Брауде Л.Ю. Скандинавская литературная сказка. М.: Наука, 1979. 208 с.

5. Бухуров М.Ф. Адыгская богатырская сказка. Нальчик: Издательский отдел КБИГИ, 2015. 160 с.

6. Гутов А.М. Художественно-стилевые традиции адыгского эпоса. Нальчик: Издательский центр «Эль-Фа», 2000. 219 c.

7. КІыщокъуэ А. Елбэздыкъуэ. Налшык: Къэбэрдей-Балъкъэр тхылъ тедзапІэ, 1948. Н. 22.

8. Сурат И.З. Русская литературная сказка: История и поэтика // Вопросы литературы. 1984. № 8. С. $261-265$.

9. ЩоджэнцІыкІу Н. Бранду. Налшык: Къэбэрдей-Балькъэр тхыль тедзапІэ, 1965. Н. 40.

10. Я Ярмыш Ю.Ф. О жанре мечты и фантазии // Радуга. 1972. № 11. С. 176-180.

11. Thompson S. The types of the folktale. A classification and bibliography. Antti Aaarne's «Verzeichnis der Märchentypen» (FFC № 3) translated and enlarged. Second revision (FFC 184). - Helsinki: Suomalainen Tiedeakatemia, 1961. $-588 \mathrm{p}$. 